\title{
Effects of the IL6 -174G >C promoter polymorphism and IL-6 serum levels on the progression of cutaneous malignant melanoma
}

\author{
TATYANA VLAYKOVA ${ }^{1}$, MATEUZH KURZAWSKI ${ }^{2}$, TANYA TACHEVA ${ }^{1}$, DIMO DIMOV ${ }^{1}$, \\ ASEN ANASTASOV $^{1}$, DENITSA VLAYKOVA ${ }^{1}$, ANI MITEVA ${ }^{3}$, NIAMH O'DONOGHUE ${ }^{1}$ and MAREK DROZDZIK ${ }^{2}$ \\ ${ }^{1}$ Department of Chemistry and Biochemistry, Medical Faculty, Trakia University, Stara Zagora 6000, Bulgaria; \\ ${ }^{2}$ Department of Experimental and Clinical Pharmacology, Pomeranian Medical University, Szczecin 70-204, Poland; \\ ${ }^{3}$ Department of Medical Ethics and Law, Faculty of Public Health, Medical University of Sofia, Sofia 1431, Bulgaria
}

Received September 3, 2019; Accepted March 26, 2020

DOI: $10.3892 / \mathrm{ol} .2020 .11740$

\begin{abstract}
Cutaneous malignant melanoma (CMM) is one of the most immunogenic types of cancer, with a 6 -fold higher rate of spontaneous regression than any other malignancy. In addition to responsiveness to different immunotherapies, the immunogenicity of CMM highlights the important role of the host immune system in the response to CMM. The present study aimed to explore the role of two functional promoter

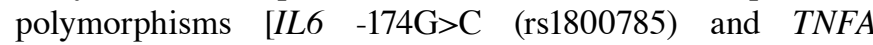
$-308 \mathrm{G}>\mathrm{A}$ (rs1800629)] in the regulation of the genes encoding the pro-inflammatory cytokines interleukin (IL)- 6 and tumor necrosis factor- $\alpha$, specifically in patients with CMM. A total of 76 patients with CMM and 200 control subjects were genotyped using PCR-restriction fragment length polymorphism. The genotype frequencies for both single nucleotide polymorphisms (SNPs) did not differ significantly between the patients and controls $(\mathrm{P}=0.358$ and $\mathrm{P}=0.810$ for IL6 and TNFA, respectively). However, compared with carriers of C-allele genotypes $(\mathrm{CG}+\mathrm{CC})$, patients with the IL6 -174GG genotype exhibited more advanced melanoma (Clark scale $\geq 3$; $\mathrm{P}=0.037$ ) and shorter survival times, particularly those who worked outdoors (in conditions with increased sunlight exposure; $\mathrm{P}=0.016$ ). Furthermore, the serum IL-6 levels of patients with CMM were significantly higher than those of the control subjects, which were associated with unfavorable blood and serum characteristics and tumor progression (development of new distant metastases; $\mathrm{P}=0.004$ ), and with a shorter overall survival time $(\mathrm{P}=0.042)$. Using a Cox proportional hazard model, the IL6 -174GG genotype was found to be an independent prognostic factor for reduced survival time $(\mathrm{P}=0.030)$, together with sex (being male; $\mathrm{P}=0.004$ ) and occupations
\end{abstract}

Correspondence to: Professor Tatyana Vlaykova, Department of Chemistry and Biochemistry, Medical Faculty, Trakia University, 11 Armeiska Str., Stara Zagora 6000, Bulgaria

E-mail: tvlaykova@abv.bg

Key words: melanoma, cytokines, polymorphism, interleukin-6, tumor necrosis factor- $\alpha$ with higher exposure to sunlight $(\mathrm{P}=0.047)$. In conclusion, the results of the present study indicated that the promoter polymorphisms IL6 $-174 \mathrm{G}>\mathrm{C}$ and TNFA $-308 \mathrm{G}>\mathrm{A}$ are not predisposing factors for CMM. However, the IL6 -174G $>\mathrm{C}$ SNP and IL-6 serum concentrations are likely to influence the progression of the disease, and the GG genotype and higher IL-6 serum levels may indicate shorter survival.

\section{Introduction}

Cutaneous malignant melanoma (CMM) is the most life-threatening primary skin malignancy, with a high global incidence rate amongst the Caucasian population. In Bulgaria, $>470$ new cases of melanoma are diagnosed each year (1). Once diagnosed, CMM can remain latent for a long period of time or can rapidly metastasize. Following distant metastasis, patient prognosis is poor, with an average survival time of 6-8 months, with only $11 \%$ of patients surviving beyond 2 years (2-4).

Numerous studies have investigated the genetic factors involved in the development of sporadic melanoma, including genes involved in the regulation of skin pigmentation, the cell cycle, DNA repair, the oxidative stress defense system and the production of immune modulatory mediators (5-12). Previous evidence also suggested that patients with CMM mounted an efficient immune response towards the tumor leading in some cases to spontaneous regression, although in most cases these responses did not prevent tumor progression $(13,14)$. The pro-inflammatory cytokines interleukin (IL)- 6 and tumor necrosis factor- $\alpha$ (TNF- $\alpha$ ) are among the factors involved in this response $(13,15)$. IL-6 is a major pro-inflammatory mediator produced by various cell types, including melanoma cells, which exerts different biological activities towards a variety of target cells $(16,17)$. IL-6 is reportedly involved in the differentiation of myeloid-derived suppressor cells and the reinforcement of their suppressive function; it is also associated with increased production of immunosuppressive cytokines by tumor cells, and increased metastasis in melanoma $(18,19)$. Furthermore, the expression of IL-6 has been shown to promote the progression of CMM. Elevated pre-treatment levels of serum IL-6 have been determined as an independent prognostic biomarker of 
reduced overall survival (20). Moreover, the pro-tumorigenic effects of IL-6 have been attributed to its regulatory role in tumor angiogenesis, proliferation, survival and tumor cell motility $(15,21,22)$. The effects of IL- 6 are mediated by the stimulation of signal transducer and activator of transcription 3 , which profoundly influences melanoma angiogenesis and cellular proliferation by transcriptionally regulating basic fibroblast growth factor, vascular endothelial growth factor, matrix metalloproteinase-2, Wnt family member 5A, Twist and $\mathrm{N}$-cadherin $(22,23)$.

TNF- $\alpha$ also plays a role in the development of CMM. Notably, increased TNF- $\alpha$ expression, stimulated by exposure to UV radiation, has been reported to contribute to antitumor immune escape (13). Together with IL-6, TNF- $\alpha$ has been suggested as one of the key modulators of melanoma cell aggressiveness, which these cells secrete in large volumes to initiate a cascade of effects, such as upregulation of matrix metalloproteinases (24). Conflictingly, TNF- $\alpha$ has been reported to both inhibit and promote tumor growth $(25,26)$.

The genes encoding TNF- $\alpha$ and IL- 6 are highly polymorphic due to a variety of single nucleotide polymorphisms (SNPs) in their regulatory and coding sequences. rs1800795, a SNP in the promoter region of the IL6 gene $(-174 \mathrm{G}>\mathrm{C})$ is reportedly associated with constitutive IL-6 expression, which results in higher IL-6 expression in carriers of the GG/GC genotype, compared with those of the CC genotype (27).

A G $>$ A substitution at position -308 in the promoter region of the TNFA gene has also been identified, and the -308A allele has been associated with enhanced TNF- $\alpha$ expression in vivo and in vitro, and increased plasma levels of TNF- $\alpha$ compared with the $-308 \mathrm{G}$ allele (28-30).

To date, only a limited number of studies have investigated the role of polymorphisms in the IL6 and TNFA genes in melanoma (13,31-34). Thus, the current study aimed to clarify the possible effects of the IL6 -174G $>\mathrm{C}$ and TNFA $-308 \mathrm{G}>\mathrm{A}$ SNPs on the susceptibility and prognosis of CMM in a Bulgarian population. The present study is the first, to the best of our knowledge, to describe possible effects of these polymorphisms on the progression of CMM in Bulgarian patients.

\section{Materials and methods}

Patients. In total, 76 patients with CMM treated at The Oncology Center of Stara Zagora (Stara Zagora, Bulgaria) were enrolled in the present study. All patients with melanoma diagnosed for the first time between January 2011 and December 2015, regardless of disease stage, were invited to participate in the study. Demographic data and information on working conditions were extracted from patient files. According to their occupation, the patients were divided into two groups: i) Those working in conditions less harmful for the skin (e.g., offices and schools); and ii) those working in more harmful conditions (such as agricultural workers, construction workers and those in open mine shafts). The demographic and clinical data obtained from the patients are presented in Table I. The control group comprised 200 individuals without CMM and included 94 (47\%) men and $106(53 \%)$ women aged between 19 and 85 years (median age, 58 years) from the same ethnic group and area of Bulgaria. The recruited controls were volunteers or individuals partici-
Table I. Demographic and clinical data of the patients with cutaneous malignant melanoma.

\begin{tabular}{|c|c|}
\hline Parameter & $\mathrm{N}(\%)$ \\
\hline $\operatorname{Sex}^{\mathrm{a}}$ & 76 \\
\hline Male & $31(41)$ \\
\hline Female & $45(59)$ \\
\hline Localization of the tumor $^{\mathrm{a}}$ & 60 \\
\hline Extremities (legs/arms) & $24(40)$ \\
\hline Trunk & $30(50)$ \\
\hline Head & $6(10)$ \\
\hline pT category ${ }^{\mathrm{a}}$ & 61 \\
\hline pT1-2 & $32(52)$ \\
\hline pT3-4 & $29(48)$ \\
\hline pN category ${ }^{\mathrm{a}}$ & 61 \\
\hline pN0 & $55(90)$ \\
\hline $\mathrm{pN} 1-3$ & $6(10)$ \\
\hline Metastasis $^{\mathrm{a}}$ & 60 \\
\hline No & $23(38)$ \\
\hline Yes & $37(62)$ \\
\hline pTNM clinical stage $\mathrm{e}^{\mathrm{a}}$ & 60 \\
\hline I & $22(36)$ \\
\hline II & $29(48)$ \\
\hline III & $3(5)$ \\
\hline IV & $6(10)$ \\
\hline Clark's level $^{\mathrm{a}}$ & 50 \\
\hline II & $17(34)$ \\
\hline III & $20(40)$ \\
\hline IV & $9(18)$ \\
\hline $\mathrm{V}$ & $4(8)$ \\
\hline Outcome after follow-up period ${ }^{a}$ & 75 \\
\hline Alive & $41(55)$ \\
\hline Dead & $34(45)$ \\
\hline Breslow's thickness, $\mathrm{n}=18, \mathrm{~mm}^{\mathrm{b}}$ & $2.00(0.20-4.20)$ \\
\hline $\begin{array}{l}\text { Survival after diagnosis, } \\
\mathrm{n}=75, \text { months } \mathrm{s}^{\mathrm{b}}\end{array}$ & $81.78(55.90-301.45)$ \\
\hline Overall survival, $\mathrm{n}=75$, months ${ }^{\mathrm{b}}$ & $19.42(0.49-237.52)$ \\
\hline Age at diagnosis, $n=76$, years ${ }^{b}$ & $59.74(15.49-83.76)$ \\
\hline
\end{tabular}

${ }^{a}$ Data are presented as n (\%); ${ }^{\mathrm{b}}$ data are presented as median (range). Data for some of the 76 patients regarding localization of the tumor, pT category, pN category, metastasis, pTNM clinical stage, Clark's level and outcome after follow-up period were not available.

pating in prophylactic examinations who were reported not to have cancer. The patients were treated and followed-up at the Dermatology Unit of The Oncology Center of Stara Zagora. Informed consent was obtained from all participants, and the protocol was approved by The Ethics Committee of The Medical Faculty of Trakia University (Stara Zagora, Bulgaria). The study was also performed in accordance with the ethical standards of the 1964 Declaration of Helsinki and its later amendments, or comparable ethical standards. 


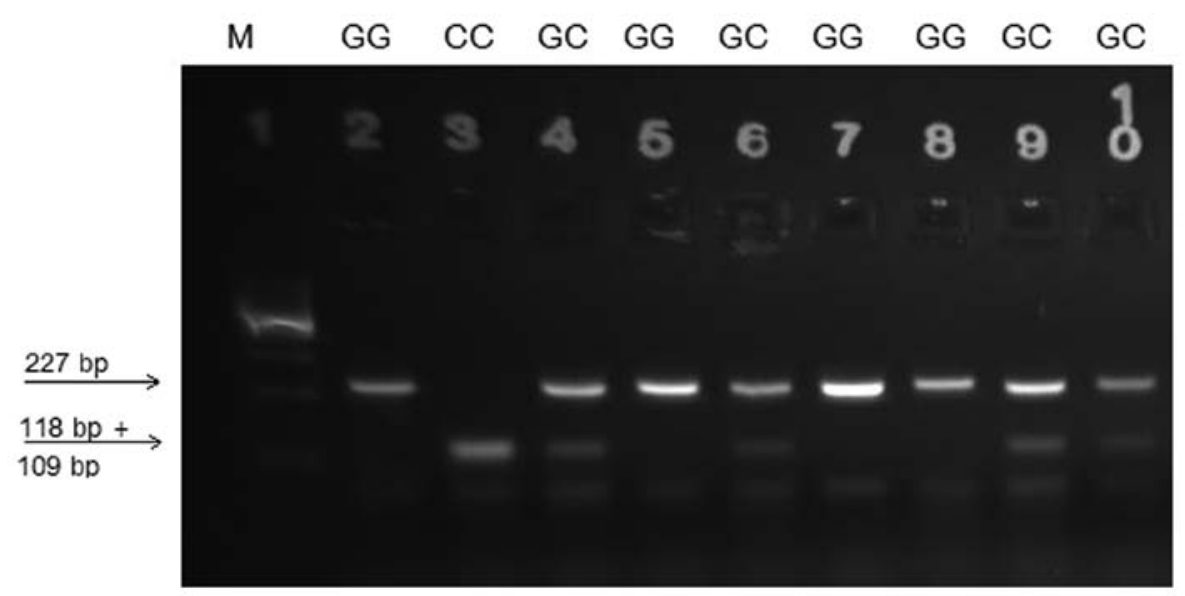

Figure 1. Agarose gel visualization of PCR-restriction fragment length polymorphism products in genotyping for the IL6 -174G $>$ C single nucleotide polymorphism. Only the bigger bands of 227, 118 and 109 bp in length are visible. IL6, interleukin-6; bp, base pair; M, marker.

DNA isolation. Genomic DNA was isolated from $0.2 \mathrm{ml}$ whole blood using the GenElute ${ }^{\mathrm{TM}}$ Mammalian Genomic DNA Miniprep kit (Sigma-Aldrich; Merck KGaA). The isolated DNA was stored at $-80^{\circ} \mathrm{C}$. DNA concentration was determined using the NanoVue ${ }^{\mathrm{TM}}$ Spectrophotometer (GE Healthcare), and purity was assessed by calculating the ratio of the optical density at 260 and $280 \mathrm{~nm}$. The purity and quality of the DNA samples was also confirmed by electrophoresis, using a $1 \%$ agarose gel.

Genotyping for TNFA -308G $>$ A (rs1800629) and IL6 -174G $>C$ (rs1800795) SNPs. Genotyping was performed using a PCR-restriction fragment length polymorphism (RFLP)-based method, as previously described (35). The amplification reactions were performed in a final volume of $12 \mu \mathrm{l}$ using the Mastercycler ${ }^{\circledR}$ instrument (Eppendorf). The amplification mix contained 30-50 ng genomic DNA, $0.8 \mathrm{pmol} / \mu \mathrm{l}$ each primer, $200 \mu \mathrm{M}$ dNTPs, $1.2 \mu 1$ 10X buffer with $15 \mathrm{mM}$ $\mathrm{MgCl}_{2}$ (Sigma-Aldrich; Merck KGaA), 0.5 U Taq Polymerase (Sigma-Aldrich; Merck KGaA) and double-distilled $\mathrm{H}_{2} \mathrm{O}$ to a final volume of $12 \mu \mathrm{l}$. The primers used were as follows: TNF- $\alpha$, forward 5'-AGGCAATAGGTTTTGAGGGCCAT-3', reverse 5'-TCCTCCCTGCTCCGATTCCG-3'; IL-6, forward 5'-TTGTCAAGACATGCCAAGTGCT-3' and reverse 5'-GCC TGAGAGACATCTCCAGTCC-3'.

Thermocycling conditions for $r s 1800629$ were: i) Preamplification denaturation at $95^{\circ} \mathrm{C}$ for $3 \mathrm{~min}$; ii) 5 cycles of denaturation for $30 \mathrm{sec}$ at $94^{\circ} \mathrm{C}$, annealing for $30 \mathrm{sec}$ at $58^{\circ} \mathrm{C}$, and polymerization for $30 \mathrm{sec}$ at $72^{\circ} \mathrm{C}$; iii) 30 cycles of denaturation for $30 \mathrm{sec}$ at $94^{\circ} \mathrm{C}$, annealing for $30 \mathrm{sec}$ at $56^{\circ} \mathrm{C}$ and polymerization for $30 \mathrm{sec}$ at $72^{\circ} \mathrm{C}$; and iv) final extension at $72^{\circ} \mathrm{C}$ for $7 \mathrm{~min}$.

For $r s 1800795$, the thermocycling conditions were: i) Pre-amplification denaturation at $95^{\circ} \mathrm{C}$ for $3 \mathrm{~min}$; ii) 35 cycles of denaturation for $30 \mathrm{sec}$ at $95^{\circ} \mathrm{C}$, annealing for $30 \mathrm{sec}$ at $62^{\circ} \mathrm{C}$ and polymerization for $30 \mathrm{sec}$ at $72^{\circ} \mathrm{C}$; and iii) final extension at $72^{\circ} \mathrm{C}$ for $5 \mathrm{~min}$.

Restriction digestion for the $r s 1800629$ SNP was performed in a final volume of $16 \mu \mathrm{l}$ with $12 \mu \mathrm{l} \mathrm{PCR}$ product and $4.8 \mathrm{U}$ $N c o$ I in $4 \mu \mathrm{l} 1 \mathrm{X}$ ONE Buffer (EUREX Sp. $\mathrm{z}$ o.o.) for $16 \mathrm{~h}$ at $37^{\circ} \mathrm{C}$. The restriction digestion reaction for the $r s 1800795$
SNP was performed in a final volume of $17 \mu \mathrm{l}$ with $12 \mu \mathrm{l}$ PCR product and $3 \mathrm{U}$ HinI in $5 \mu \mathrm{l} 1 \mathrm{X}$ Tango buffer (Thermo Fisher Scientific, Inc.) for $16 \mathrm{~h}$ at $37^{\circ} \mathrm{C}$. The obtained restriction fragments were analyzed using electrophoresis with a $3.5 \%$ agarose gel stained with ethidium bromide (Sigma-Aldrich; Merck $\mathrm{KGaA}$ ), and detected using a UV transilluminator (Cleaver Scientific Ltd.). The results were assessed using the Gel documentation system EC3 Imaging system (Ultra-Violet Products Ltd.).

Measurement of IL-6 serum concentration. Serum IL-6 levels of 20 control individuals and 59 patients with CMM were determined using a commercial ELISA kit (cat. no. D6050; R\&D Systems, Inc.) according to the manufacturer's protocol. The IL-6 concentrations were recorded in comparison to the standards included in the kit and are presented in $\mathrm{pg} / \mathrm{ml}$ serum. Statistical analysis. Statistical analysis was performed using SPSS v16.0 (SPSS, Inc.). The descriptive data, including the mean, SEM and median, were assessed. Kolmogorov-Smirnov's test and Shapiro-Wilks' W-test were used to analyze the normality of the continuous variables. Continuous variables with normal distribution were compared between $\geq 2$ independent groups using one-way ANOVA followed by a least significant difference post hoc test. Variables with non-normal distribution were compared using a Mann-Whitney U test. The manifestation frequencies of the qualitative (categorical) variables were determined in $2 \times 3$ and $2 \times 2$ cross-tables and were evaluated using the $\chi^{2}$ test. Fisher's exact test was used as appropriate (when the expected numbers of $\geq 1$ of the cells of the $2 \times 2$ cross-tables were $<5$ ). The correlations between the quantitative variables were evaluated using Pearson or Spearman's test according to the distribution (normal or skewed, respectively). The odds ratios and 95\% CI values were calculated by binary logistic regression analysis for evaluation of the risk of outcome occurrence (development of melanoma). Hardy-Weinberg equilibrium (HWE) was tested among the controls and patients using the $\chi^{2}$ test.

Cumulative survival curves were constructed using the Kaplan-Meier method, and the differences in survival were calculated using the log rank test. The prognostic significance of various factors regarding patient survival after surgery was 
Table II. Genotype and allele frequencies of the IL6 -174G $>C$ gene polymorphism in patients with cutaneous melanoma ( $\mathrm{n}=59$ and $n=118$, respectively) and controls ( $n=173$ and $n=346$, respectively) (binary logistic regression analysis).

A, Genotype frequency $\left(\mathrm{P}=0.358 ; \chi^{2}\right.$ test $)$

\begin{tabular}{|c|c|c|c|c|}
\hline Variable & Patients, n (frequency) & Controls, n (frequency) & OR $(95 \% \mathrm{CI})$ & P-value \\
\hline GG & $30(0.508)$ & $74(0.428)$ & 1.0 (reference) & \\
\hline GC & $22(0.373)$ & $83(0.480)$ & $0.654(0.347-1.231)$ & 0.188 \\
\hline $\mathrm{CC}$ & $7(0.119)$ & $16(0.092)$ & $1.079(0.403-2.888)$ & 0.879 \\
\hline $\mathrm{GC}+\mathrm{CC}$ & $29(0.492)$ & $99(0.572)$ & $0.723(0.399-1.307)$ & 0.283 \\
\hline
\end{tabular}

$\mathrm{B}$, Allele frequency $\left(\mathrm{P}=0.878 ; \chi^{2}\right.$ test $)$

\begin{tabular}{lccl}
\hline Variable & Patients, $n$ (frequency) & Controls, $n$ (frequency) & OR (95\% CI) \\
\hline$-174 G$ & $82(0.695)$ & $231(0.668)$ & 1.0 (reference) \\
$-174 C$ & $36(0.305)$ & $115(0.332)$ & $0.882(0.563-1.382)$ \\
\hline
\end{tabular}

Frequency was calculated by dividing the number of patients in each group by the total number of patients. OR, odds ratio.

Table III. Biochemical/blood parameters in patients with cutaneous melanoma and different IL6 -174G>C genotypes.

\begin{tabular}{lcrr}
\hline Biochemical/blood parameters & IL6 -174GG & IL6 -174GC & IL6 - 174CC \\
\hline AsAT, U/1 & $21.34 \pm 2.03$ & $24.77 \pm 5.97$ & $18.00 \pm 2.51$ \\
AlAT, U/1 & $22.21 \pm 3.38$ & $20.82 \pm 7.40$ & $18.40 \pm 3.11$ \\
GGT, U/1 & $51.17 \pm 18.03$ & $21.50 \pm 4.50$ & $54.00 \pm 17.62$ \\
LDH, U/1 & $215.20 \pm 33.26$ & $203.00 \pm 25.7$ & $246.33 \pm 44.54$ \\
RBC, $10^{12}$ cells/1 & $4.82 \pm 0.14$ & $4.71 \pm 0.11$ & $4.62 \pm 0.30$ \\
WBC, $10^{9}$ cells/1 & $6.94 \pm 0.53$ & $7.59 \pm 0.46$ & $9.16 \pm 2.09$ \\
Lymphocytes, \% & $36.27 \pm 3.01$ & $32.80 \pm 3.65$ & $31.70 \pm 4.93$ \\
Granulocytes, \% & $62.88 \pm 1.75$ & $62.65 \pm 4.45$ & $71.35 \pm 1.35$ \\
\hline
\end{tabular}

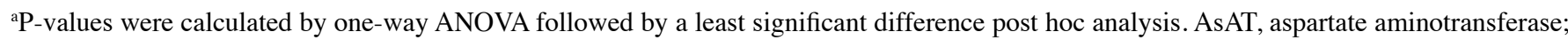
AlAT, alanine aminotransaminase; GGT, $\gamma$-glutamyl transferase; LDH, lactate dehydrogenase; RBC, red blood cell; WBC, white blood cell; IL6, interleukin-6.

determined by univariate and multivariate Cox regression analyses. $\mathrm{P}<0.05$ was considered to indicate a statistically significant difference.

\section{Results}

IL6 $-174 G>C S N P$. Genotyping of the $-174 \mathrm{G}>\mathrm{C}$ polymorphism in the promoter region of IL6 was performed by PCR-RFLP. The resulting PCR product was $299 \mathrm{bp}$ in length, and the restriction reaction resulted in three fragments for the wild-type $\mathrm{G}$ allele (227, 50 and $13 \mathrm{bp}$ ). For the variant $\mathrm{C}$ allele (CC genotype), the restriction reaction resulted in four fragments of 118, 109, 50 and 13 bp (Fig. 1).

For this SNP, 59 patients with CMM and 173 control individuals were successfully genotyped. The distribution of the genotypes did not deviate from HWE in either group $(\mathrm{P}=0.997$ and $\mathrm{P}=0.799$, respectively; $\chi^{2}$ test). The genotype distributions in the patient group were $30(50.8 \%) \mathrm{GG}$ carriers, 22 (37.3\%) GC carriers and $7(11.9 \%) \mathrm{CC}$ carriers. The control group comprised
74 (42.8\%) carriers of the GG genotype, 83 (48.0\%) with the GC genotype and $16(9.2 \%)$ with the $\mathrm{CC}$ genotype. Both genotype and allelic distributions did not differ between the patients and controls ( $\mathrm{P}=0.358$ and $\mathrm{P}=0.878 ; \chi^{2}$ test; Table II).

In patients with CMM, there were no associations between different genotypes and biochemical/blood parameters such as total protein, albumin, glucose, bilirubin, creatinine, enzymes [aspartate aminotransferase (AsAT), alanine aminotransferase (AlAT), $\gamma$-glutamyl transferase (GGT) and lactate dehydrogenase (LDH)], red blood cell count, white blood cell (WBC) count and the percentages of WBC subpopulations (Table III). According to the Clark scale (36), carriers of the GG genotype predominantly exhibited more advanced melanoma (Clark 3, 4 and 5) than those with $\mathrm{C}$ allele genotypes $(\mathrm{GC}+\mathrm{CC})\left(\mathrm{P}=0.037 ; \chi^{2}\right.$ test; Fig. 2). Similarly, GG carriers more frequently possessed thicker tumors ( $\geq 2 \mathrm{~mm} ; 75 \%$ ) than patients with other genotypes (52.4\%; $\mathrm{P}=0.114 ; \chi^{2}$ test; Fig. 3 ).

On patient follow-up, the survival time after diagnosis of IL6 -174GG genotype carriers was shorter, although not 
Genotypes for IL6 -174G >C SNP and clark scale

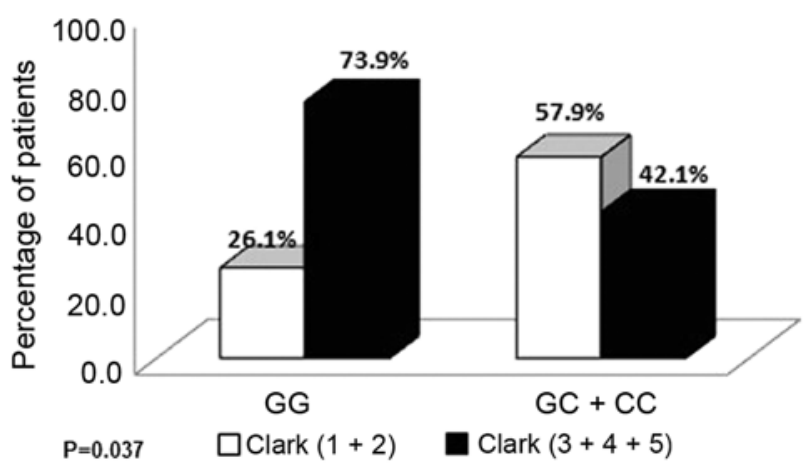

Figure 2. Association between the genotype distribution of the $I L 6-174 \mathrm{G}>\mathrm{C}$ SNP and the depth of distribution in the skin of patients with cutaneous malignant melanoma (Clark scale). SNP, single nucleotide polymorphism; IL6, interleukin-6.

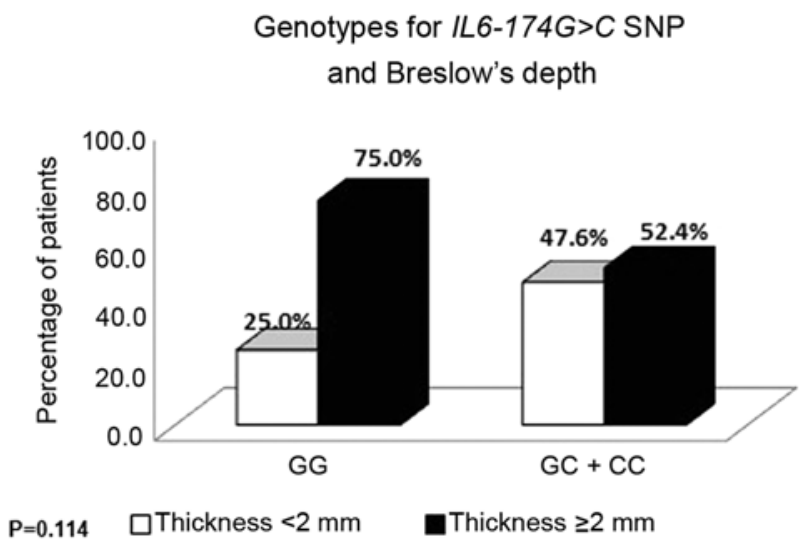

Figure 3. Association between the genotype distribution of the $I L 6-174 \mathrm{G}>\mathrm{C}$ SNP and Breslow's depth of tumors from the patients with cutaneous malignant melanoma. SNP, single nucleotide polymorphism; IL6, interleukin 6.

significantly, than those with a genotype with $\geq 1$ variant IL6 -174C allele (GC+CC) (mean, 132.58 vs. 166.55 months; $\mathrm{P}=0.299$; log rank test; Fig. 4). When patients were categorized according to their working conditions, those carrying the GG genotype and in occupational conditions with longer periods of sunlight exposure (so called 'high risk conditions') had significantly shorter survival times (24.09 months) compared with carriers of $\mathrm{C}$ allele genotype (104.33 months; $\mathrm{P}=0.016$; $\log$ rank test; Fig. 5A). Similar results, although not significant, were obtained for the subgroup of patients working indoors, i.e., in conditions with rare sunlight exposure (so called 'low risk conditions'): The mean survival period of patients with the GG genotype who worked indoors was 185.73 months, while that of the patients with $\mathrm{C}$ allele genotypes $(\mathrm{GC}+\mathrm{CC}$ group) was 256.00 months ( $\mathrm{P}=0.121$; log rank test; Fig. 5B).

Serum IL-6 levels between patients with CMM (median, $5.68 \mathrm{pg} / \mathrm{ml}$; mean $\pm \mathrm{SEM}), 20.57 \pm 5.89 \mathrm{pg} / \mathrm{ml}$ ) and the control subjects (median, $4.17 \mathrm{pg} / \mathrm{ml}$; mean \pm SEM, $5.02 \pm 0.74 \mathrm{pg} / \mathrm{ml}$ ) differed with marginal significance ( $\mathrm{P}=0.033$; Fig. 6). No significant difference was observed when comparing the three $-174 \mathrm{G}>\mathrm{C}$ genotypes of both the patient and control groups $(\mathrm{P}=0.323$ and 0.104 , respectively; data not shown). However, the IL-6 level was significantly lower in control subjects with

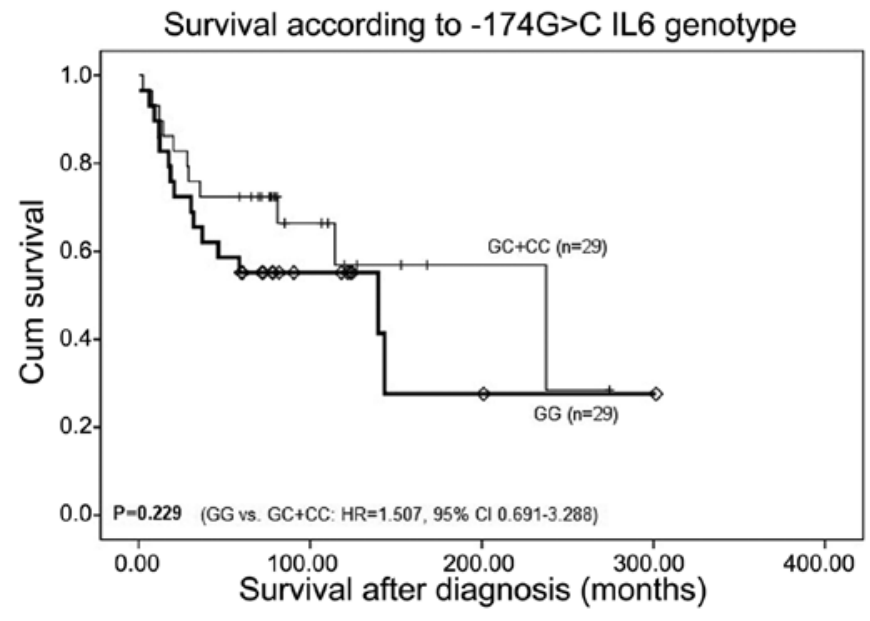

Figure 4. Survival of patients with cutaneous malignant melanoma according to $I L 6-174 \mathrm{G}>\mathrm{C}$ single nucleotide polymorphism genotype (Log rank test). IL6, interleukin-6; HR, hazard ratio; Cum, cumulative.
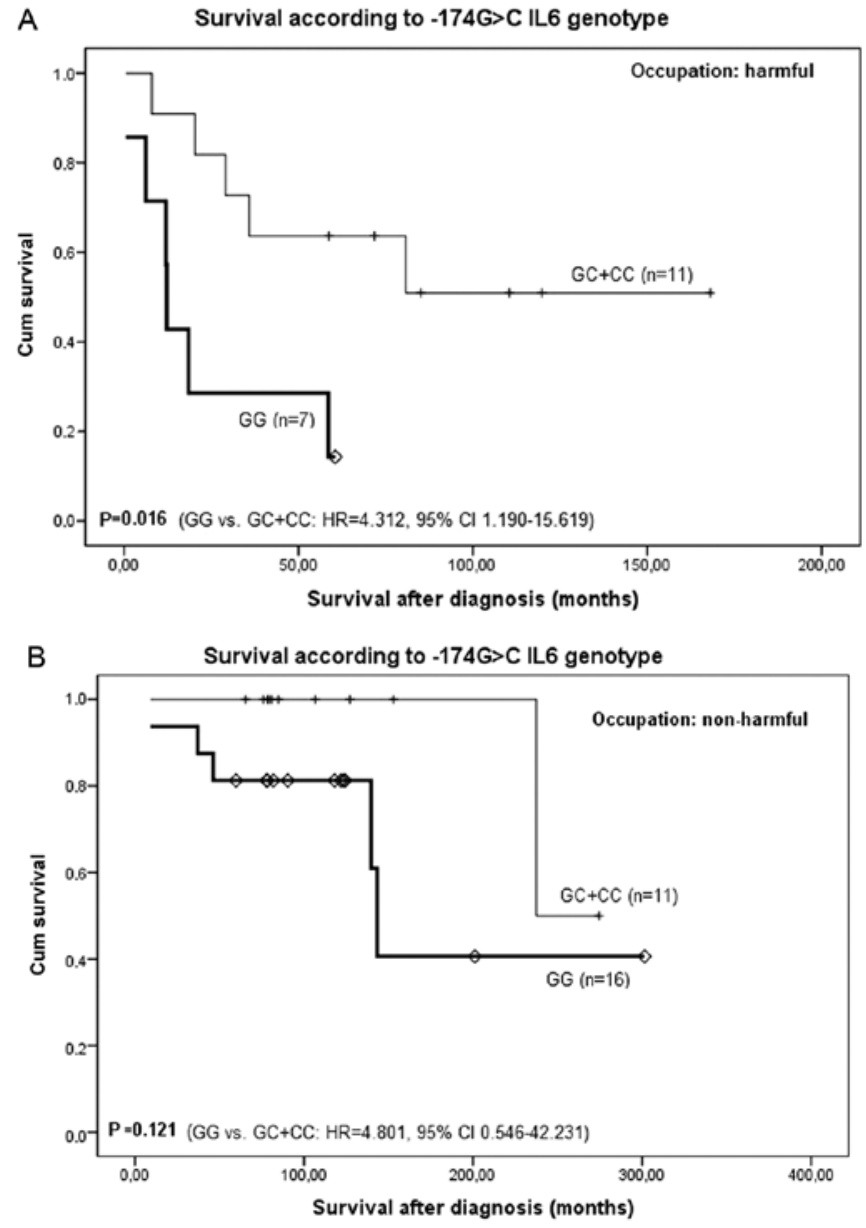

Figure 5. Survival of patients with cutaneous malignant melanoma according to $I L 6-174 \mathrm{G}>\mathrm{C}$ single nucleotide polymorphism genotype and occupational conditions. (A) Patients with occupational conditions involving longer exposure to sunlight (outdoor work, harmful conditions). (B) Patients with occupational conditions involving rare exposure to sunlight (indoor work, non-harmful conditions). IL6, interleukin-6; HR, hazard ratio; Cum, cumulative.

the GG genotype (median, $3.02 \mathrm{pg} / \mathrm{ml}$ ), compared with those with variant $\mathrm{C}$ allele genotypes $(\mathrm{GC}+\mathrm{CC} ; 5.01 \mathrm{pg} / \mathrm{ml} ; \mathrm{P}=0.039$; Fig. 7). Although not statistically significant, a similar trend 


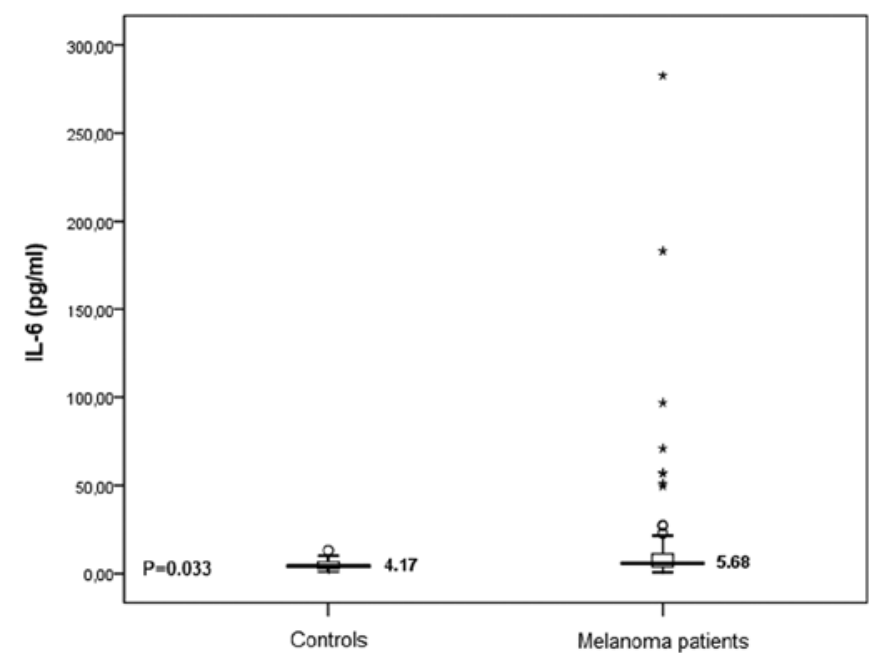

Figure 6. Serum IL-6 levels in patients with cutaneous malignant melanoma and control subjects. Data are presented as box-and-whiskers plots with medians. Statistical analysis was performed using a Mann-Whitney U test $(\mathrm{P}=0.033)$. Open circles represent outliers; stars represent extreme cases. IL-6, interleukin-6.

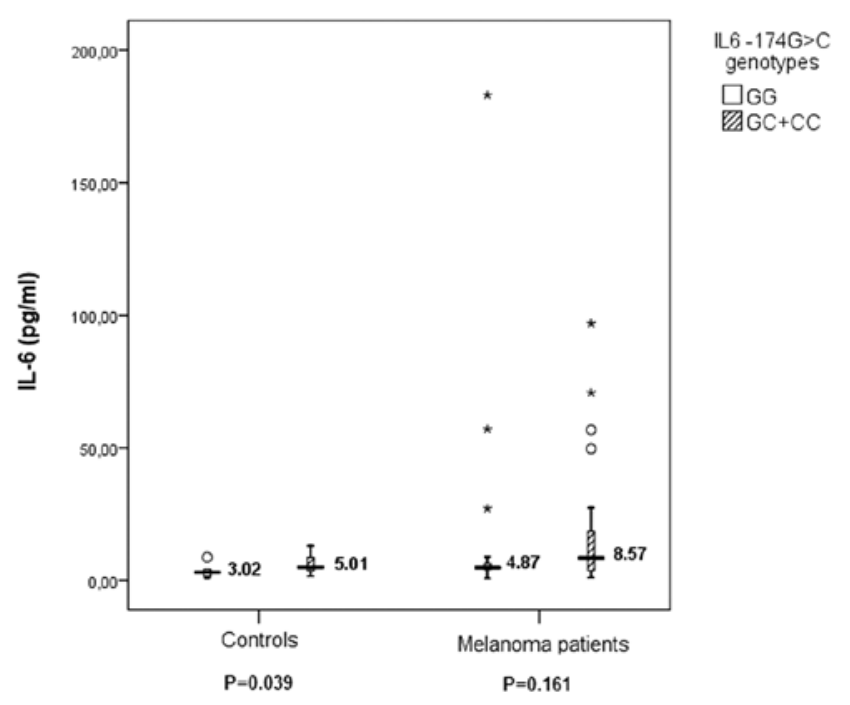

Figure 7. Serum IL-6 levels in patients with cutaneous malignant melanoma and control subjects according to the $I L-6-174 \mathrm{G}>\mathrm{C}$ genotypes. Data are presented as box-and-whiskers plots with medians. Statistical analysis was performed using a Mann-Whitney $\mathrm{U}$ test $(\mathrm{P}=0.039$ for controls and $\mathrm{P}=0.161$ for melanoma patients). Open circles represent outliers; stars represent extreme cases. IL-6, interleukin-6.

was observed in the patient group (median, $4.87 \mathrm{pg} / \mathrm{ml}$ vs. $8.57 \mathrm{pg} / \mathrm{ml}$; P=0.161; Fig. 7).

Serum IL-6 levels were not associated with clinical or histological tumor parameters such as the Clark scale $(1+2$ vs. $3+4+5 ; \mathrm{P}=0.404)$, Breslow's thickness $(<2 \mathrm{~mm}$ vs. $\geq 2 \mathrm{~mm} ; \mathrm{P}=0.808$ ), TNM staging (37) (1 vs. 2 vs. 3 vs. 4; $\mathrm{P}=0.187)$ and the presence of distant metastases at the time of diagnosis ( $\mathrm{P}=0.440$; data not shown). However, the IL-6 serum levels between the patients with disease progression and development of new distant metastases (median, $22.81 \mathrm{pg} / \mathrm{ml}$ ), and those without new distant metastases (median, $5.10 \mathrm{pg} / \mathrm{ml}$ ), were significantly different $(\mathrm{P}=0.004$; Fig. 8A). Moreover, the serum levels differed significantly between patients whose occupation
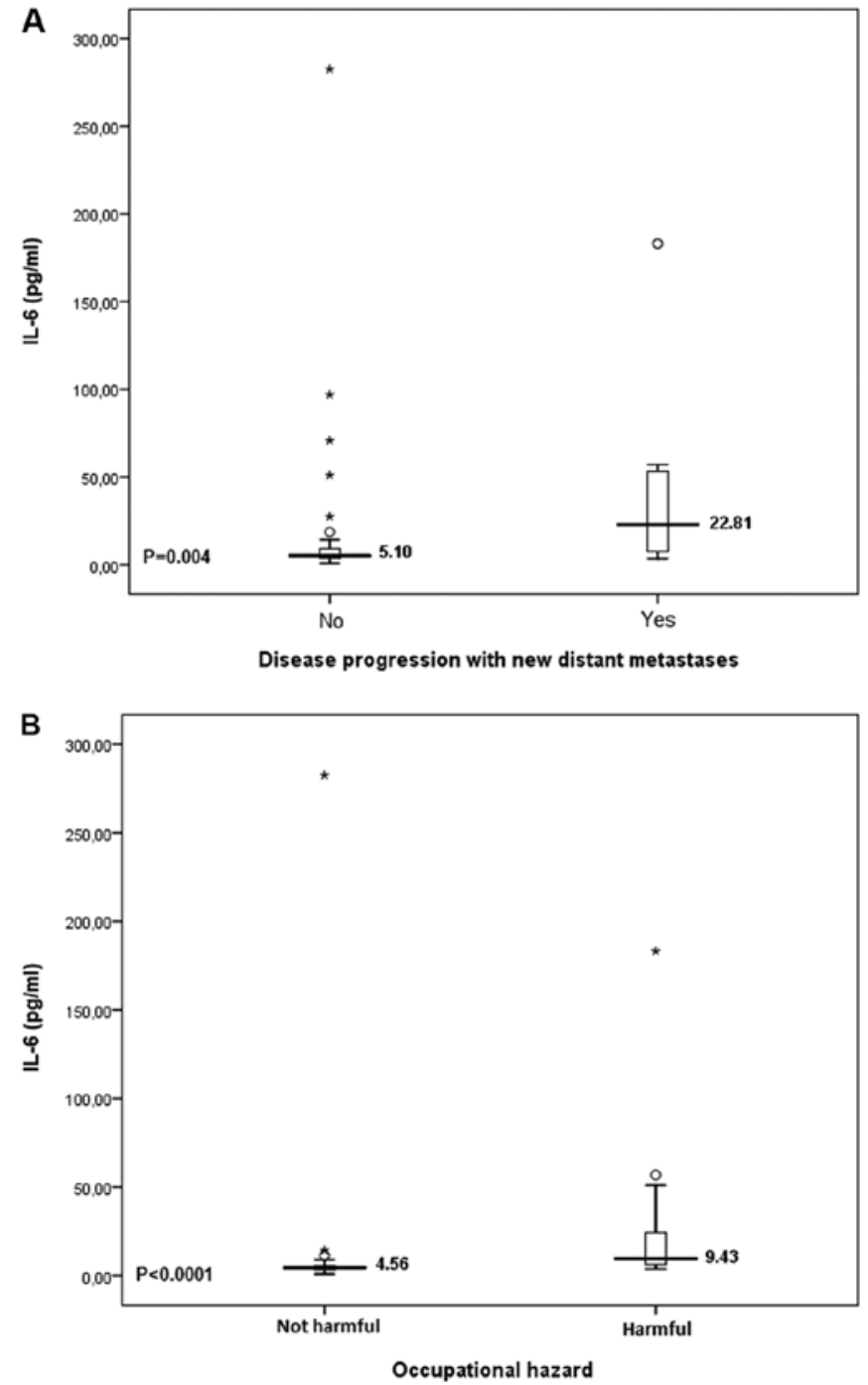

Figure 8. Serum IL-6 levels in patients with cutaneous malignant melanoma (A) according to disease progression and development of new distant metastases $(\mathrm{P}=0.004)$ and $(\mathrm{B})$ according to occupational hazard $(\mathrm{P}<0.0001$, vs. patients who worked indoors). Data are presented as box-and-whiskers plots with medians. Statistical analysis was performed using a Mann-Whitney $\mathrm{U}$ test. Open circles represent outliers; stars represent extreme cases. IL-6, interleukin-6.

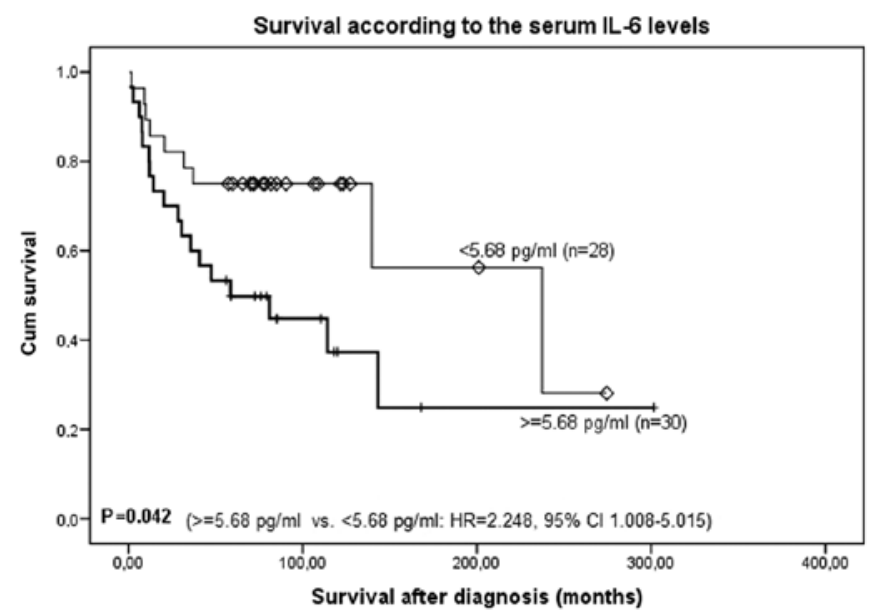

Figure 9. Survival of patients with cutaneous malignant melanoma according to IL-6 serum levels. Cut-off, $5.68 \mathrm{ng} / \mathrm{ml}$ (median serum IL-6 level in patients). IL-6, interleukin-6. 
Table IV. Correlation between serum IL-6 and serum biochemical and blood parameters in patients with cutaneous melanoma.

\begin{tabular}{lcccccc}
\hline Biochemical/ blood parameters & AsAT & AlAT & GGT & Serum glucose & Serum creatinine & WBC \\
\hline @ & 0.408 & 0.328 & 0.758 & 0.621 & 0.434 & 0.384 \\
P-value & 0.015 & 0.050 & 0.007 & $<0.0001$ & 0.015 & 0.019
\end{tabular}

AsAT, aspartate aminotransferase; AlAT, alanine aminotransaminase; GGT, $\gamma$-glutamyl transferase; WBC, white blood cell.

Table V. Univariate and multivariate Cox proportional analysis of the survival of patients with cutaneous melanoma. (pTNM staging system is not included in multivariate analysis because it depends on another variable in the analysis, the presence of lymph node metastases, LN metastases)

\begin{tabular}{|c|c|c|c|c|c|c|}
\hline \multirow[b]{2}{*}{ Variable } & \multicolumn{2}{|c|}{ Univariate analysis } & \multicolumn{2}{|c|}{$\begin{array}{l}\text { Multivariate analysis model 1, } \\
\qquad \mathrm{n}=30\end{array}$} & \multicolumn{2}{|c|}{$\begin{array}{l}\text { Multivariate analysis model 2, } \\
\qquad \mathrm{n}=32\end{array}$} \\
\hline & P-value & $\mathrm{HR}(95 \% \mathrm{CI})$ & P-value & $\mathrm{HR}(95 \% \mathrm{CI})$ & P-value & $\mathrm{HR}(95 \% \mathrm{CI})$ \\
\hline \multicolumn{7}{|l|}{ Sex, category (n) } \\
\hline Male (32) vs. female (44) & $<0.0001$ & $4.51(2.19-9.28)$ & 0.015 & $44.29(2.08-942.27)$ & 0.004 & $14.09(2.34-84.74)$ \\
\hline Age & 0.010 & 1.03 & 0.217 & $1.06(0.97-1.15)$ & 0.105 & $1.06(0.99-1.15)$ \\
\hline \multicolumn{7}{|l|}{ Clark score, category (n) } \\
\hline $3+4+5$ (34) vs. $1+2(18)$ & 0.024 & $4.41(1.21-16.04)$ & 0.263 & $3.52(0.39-31.90)$ & 0.719 & $1.41(0.22-9.21)$ \\
\hline \multicolumn{7}{|l|}{ LN metastasis, category (n) } \\
\hline Yes (6) vs. no (55) & $<0.0001$ & $9.54(3.48-26.26)$ & 0.098 & $42.27(0.50-358.20)$ & 0.211 & $16.43(0.20-132.40)$ \\
\hline \multicolumn{7}{|l|}{ pTNM staging, category (n) } \\
\hline III-IV (10) vs. I-II (54) & 0.002 & $4.04(1.67-9.76)$ & & & & \\
\hline \multicolumn{7}{|l|}{ Occupational hazard, category (n) } \\
\hline Present (36) vs. absent (30) & 0.022 & $3.03(1.18-7.81)$ & 0.188 & $0.11(0.01-2.93)$ & 0.047 & $6.83(1.03-45.45)$ \\
\hline \multicolumn{7}{|l|}{ Hemoglobin, g/l (n) } \\
\hline$<120(10)$ vs. $\geq 120(39)$ & 0.001 & $5.09(2.01-12.88)$ & 0.588 & $2.29(0.11-46.29)$ & 0.248 & $13.60(0.16-113.70)$ \\
\hline \multicolumn{7}{|l|}{ Serum IL-6, pg/ml (n) } \\
\hline$\geq 5.68$ (30) vs. $<5.68$ (28) vs. & 0.048 & $2.25(1.01-5.02)$ & 0.299 & $5.67(0.21-149.70)$ & & \\
\hline$-174 G>C I L 6, \mathrm{SNP}(\mathrm{n})$ & & & & & & \\
\hline GG (29) vs. GC+CC (29) & 0.303 & $1.51(0.69-3.29)$ & & & 0.030 & $9.61(1.24-74.28)$ \\
\hline
\end{tabular}

was associated with increased exposure to sunlight (presence of occupational hazard; median, $9.43 \mathrm{pg} / \mathrm{ml}$ ) and those who worked indoors (median, $4.56 \mathrm{pg} / \mathrm{ml}$; $\mathrm{P}<0.0001$; Fig. 8B).

IL-6 serum levels were positively correlated with liver-specific enzyme levels, including AsAT $(\mathrm{Q}=0.408$; $\mathrm{P}=0.015)$ AlAT $(\mathrm{Q}=0.328 ; \mathrm{P}=0.050)$ and GGT $(\mathrm{Q}=0.758$; $\mathrm{P}=0.007)$. IL-6 was also positively correlated with blood glucose $(\mathrm{Rho}=0.621 ; \mathrm{P}<0.0001)$ and creatinine levels $(\varrho=0.434$; $\mathrm{P}=0.015)$, as well as WBC count $(\mathrm{Q}=0.384 ; \mathrm{P}=0.019$; Table IV).

Subsequently, the median patient IL-6 serum level $(5.68 \mathrm{pg} / \mathrm{ml})$ was selected as the cut-off value for survival analysis. Patients with higher serum IL-6 levels exhibited significantly shorter survival times after diagnosis, compared with those with IL-6 levels below the cut-off (median, 58.63 vs. 237.52 months; $\mathrm{P}=0.042$; Fig. 9).
Cox univariate analysis demonstrated that several demographic, clinical and blood parameters had significant adverse effects on the survival of patients with CMM. These included male sex $(\mathrm{P}<0.0001)$, advanced age $(\mathrm{P}=0.010)$, occupational conditions with increased exposure to sunlight $(\mathrm{P}=0.022$, low hemoglobin levels $(\mathrm{P}=0.001)$, greater Clark scale depth $(3+4+5 ; \mathrm{P}=0.024)$ and the presence of lymph node metastases $(\mathrm{P}<0.0001)$; higher serum IL-6 levels were also adversely associated with survival $(\mathrm{P}=0.048$; Table $\mathrm{V})$.

Factors identified as significant using univariate analysis were then assessed using the multivariate Cox's proportional hazard model (Model 1). IL-6 serum level was no longer a significant factor $(\mathrm{P}=0.299)$, and only the male sex remained an independent risk factor for shorter survival time $(\mathrm{P}=0.015$; Table V). A second Cox's proportional hazard model (Model 2) 
Table VI. Genotype and allele frequencies of the TNFA -308G>A gene polymorphism in patients with cutaneous malignant melanoma ( $n=76$ and $n=152$, respectively) and controls ( $n=198$ and $n=396$, respectively).

A, Genotype frequency $\left(\mathrm{P}=0.810 ; \chi^{2}\right.$ test $)$

\begin{tabular}{lccc}
\hline Variable & Patients, $n$ (frequency) & Controls, $n$ (frequency) & OR (95\% CI) \\
\hline GG & $63(0.829)$ & $160(0.808)$ & 1.0 (reference) \\
GA & $12(0.158)$ & $33(0.167)$ & $0.924(0.449-1.901)$ \\
AA & $1(0.013)$ & $5(0.025)$ & $0.508(0.058-4.434)$ \\
GA+AA & $13(0.171)$ & $38(0.192)$ & $0.869(0.434-1.739)$ \\
\hline
\end{tabular}

$\mathrm{B}$, Allele frequency $\left(\mathrm{P}=0.878, \chi^{2}\right.$ test $)$

\begin{tabular}{lccl}
\hline Variable & Patients, n (frequency) & Controls, n (frequency) & OR (95\% CI) \\
\hline$-308 \mathrm{G}$ & $138(0.908)$ & $353(0.891)$ & 1.0 (reference) \\
$-308 \mathrm{~A}$ & $14(0.092)$ & $43(0.109)$ & $0.833(0.445-1.558)$ \\
\hline
\end{tabular}

Frequency was calculated by dividing the number of patients in each group by the total number of patients. OR, odds ratio; TNFA, tumor necrosis factor- $\alpha$.

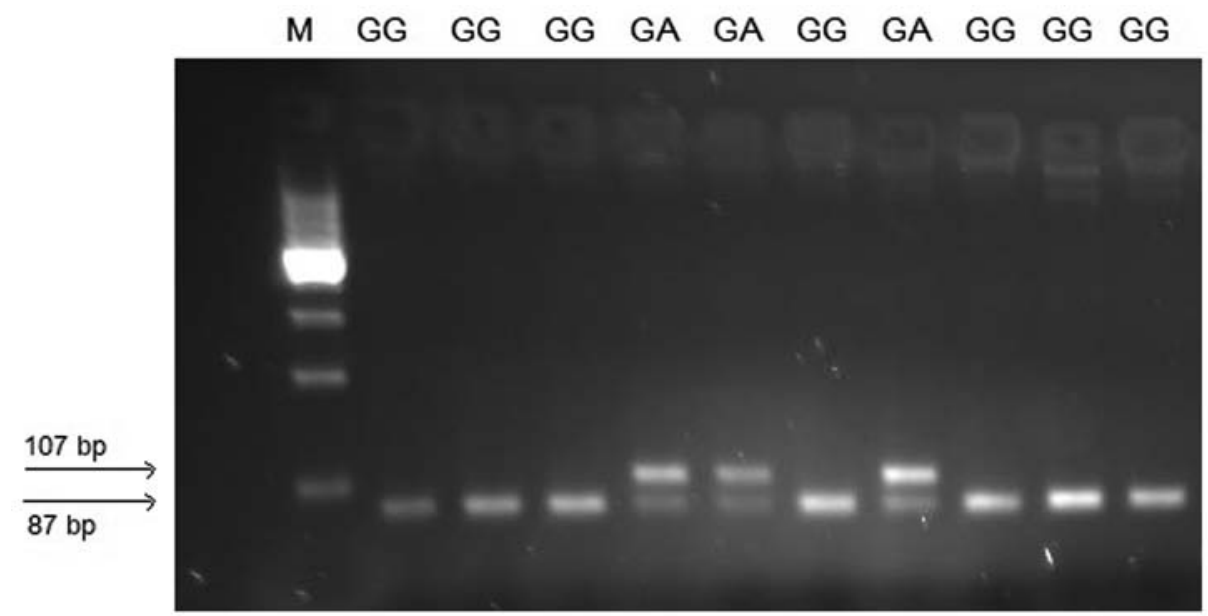

Figure 10. Agarose gel visualization of PCR-restriction fragment length polymorphism products when genotyping for the $T N F A-308 G>A$ single nucleotide polymorphism. Only the bigger bands of 107 and $87 \mathrm{bp}$ in length are visible. TNFA, tumor necrosis factor- $\alpha$; bp, base pair; M, marker.

was also used, which included genotypes with the IL6 $-174 G>C$ SNP together with all significant factors identified during univariate analysis of routine demographic, clinical and blood parameters. Male sex $(\mathrm{P}=0.004)$, occupational conditions with increased exposure to sunlight $(\mathrm{P}=0.047$ and the $\mathrm{GG}$ genotype $(\mathrm{P}=0.030)$ remained independent prognostic factors for shorter survival time (Table V).

TNFA $-308 G>A$ A SN . Genotyping for the $-308 \mathrm{G}>\mathrm{A}$ polymorphism in the TNFA promoter was performed by PCR-RFLP. The resulting PCR product was $107 \mathrm{bp}$ in length, and the subsequent restriction reaction for the $\mathrm{G}$ allele (GG genotype) resulted in 2 fragments of 87 and $20 \mathrm{bp}$. The variant A allele remained unchanged (107 bp; Fig. 10).

Genotyping of the TNFA -308G>A SNP was successfully performed in 76 patients with $\mathrm{CMM}$ and 198 control individuals. The genotype distribution in both the control and patient group did not deviate from HWE $(\mathrm{P}=0.148$ and $\mathrm{P}=0.889$, respectively; $\chi^{2}$ test). In the patient group, $63(82.9 \%)$ carried the GG genotype, $12(15.8 \%)$ were GA genotype-positive, and only one patient $(1.3 \%)$ carried the AA genotype. The genotype distribution among the controls was 160 (80.8\%) with the GG genotype, 33 (16.7\%) with GA genotype and $5(2.5 \%)$ with the AA genotype. No significant differences in genotype and allelic distribution between the patients and controls were observed $(\mathrm{P}=0.810$ and $\mathrm{P}=0.982$; $\chi^{2}$ test; Table VI). Furthermore, no associations were found between genotypes with the TNFA $-308 G>A$ SNP and biochemical or clinical parameters in patients with $\mathrm{CMM}$ (data not shown).

\section{Discussion}

Melanoma cells are derived from normal melanocytes transformed due to various extrinsic and intrinsic factors. The immune response strongly influences the development and 
progression of melanoma $(14,34)$. Previous studies identified IL-6 as one of the most important regulatory cytokines in tumor biology, which is involved in key stages of tumor development, such as proliferation, apoptosis, angiogenesis and differentiation $(38,39)$. However, IL-6 has pleiotropic effects in carcinogenesis, including strong growth-stimulating, as well as antitumor effects (39). During tumor progression, IL-6 changes from a paracrine inhibitor of normal melanocytes in the early stages, to an autocrine mitogen in the advanced stages of disease (15). Additionally, it exerts a paracrine effect on tumor angiogenesis and cells of the immune system (15). Thus, IL-6 acts as an inhibitor of tumor growth in early melanoma, but appears to be an important growth factor in advances stages of the disease $(33,40)$.

The expression of IL- 6 depends on a variety of factors, including polymorphisms in the IL6 gene. The IL6 -174G >C (rs1800795) polymorphism is localized at the promoter region of the gene, and is associated with altered promoter activity and resulting protein expression levels (41). A previous study reported 2-fold lower expression in HeLa cells transfected with a vector containing the $\mathrm{C}$ allele construct, compared with cells transfected with the $\mathrm{G}$ allele construct (41). Another in vitro study also demonstrated that the $\mathrm{G}$ allele of the IL6 $-174 G>C$ SNP was associated with an increased transcriptional response to various stimuli (42). However, the results of studies investigating the levels of circulating IL-6 are conflicting. In healthy subjects, the $\mathrm{G}$ allele genotypes (GG and GC) were associated with higher IL-6 plasma levels compared with the CC genotype (41), while Jones et al (43) detected high plasma IL-6 levels in individuals with the $\mathrm{C}$ allele and $\mathrm{CC}$ genotypes. The results of the present study are in a line with the latter study (43), although carriers of $\mathrm{C}$ allele genotypes $(\mathrm{CG}+\mathrm{CC})$ exhibited significantly higher serum IL-6 levels in the control group only, not in patients with CCM.

The effects of the IL6 -174G $>$ C SNP on the progression of different cancer types have been widely explored, with quite controversial results (27). Zhai et al (27) performed a comprehensive meta-analysis of 17 studies including 4,304 patients with various cancer types, including breast, colorectal, lung, ovarian cancer and lymphoma. This previous study assessed the association between the IL6 -174 polymorphism and cancer prognosis. No association with overall survival was observed from pooled analysis of the three genotypes with this SNP. However, the GG genotype affected patient survival compared with the $\mathrm{C}$ allele genotypes $(\mathrm{GC}+\mathrm{CC})$ in bladder, ovarian, gastric and peritoneal cancer, as well as in neuroblastoma and osteosarcoma.

To date, there are only a limited number of studies concerning the possible role of the IL6 -174G $>$ C SNP in CMM $(31,44)$. The present study is the first, to the best of our knowledge, describing the possible effect of this polymorphism on Bulgarian patients with CMM. The results of the current study concur with those aforementioned (27), which also demonstrated no significant differences in genotype or allelic frequency of the IL6-174G>C SNP between patients with CMM and controls. Thus, these results suggested that IL6 $-174 \mathrm{G}>\mathrm{C}$ is unlikely to be heavily involved in patient susceptibility to CMM $(31,44)$.

Investigating the associations between IL6 -174G >C SNP genotype frequencies and different clinical characteristics of patients with CMM, the present results suggested that the
IL6 -174 GG genotype was associated with a more advanced stage, thicker tumors and reduced overall survival. Similarly, a previous study on the role of the IL6 -174G $>$ C SNP demonstrated that the $\mathrm{C}$ allele decreased the risk of developing urinary bladder cancer, and that the GG genotype was associated with more advanced disease stages (45). By contrast, Leibovici et al (46) reported that the CC genotype was more frequently observed in the advanced stages of bladder cancer.

The association between IL6 -174G $>\mathrm{C}$ and disease progression may be due to the potential effects on IL-6 expression. The results of the present study indicated that higher serum IL-6 levels were associated with unfavorable blood/serum characteristics (poor WBC count, liver enzyme levels, blood glucose and creatinine), tumor progression (development of new distant metastases) and shorter survival time. These results concur with those of Tobin et al (19), which suggested an association between increased plasma IL-6 levels in patients with stage IV melanoma and tumor burden, as well as shorter survival.

A notable finding of the present study was the relationship between serum IL- 6 and patient working conditions. Those working outdoors with supposedly increased exposure to sunlight had significantly higher IL-6 levels compared with patients working indoors. This finding suggested that sunlight may stimulate IL-6 expression, which is in line with previous observations of increased serum levels of the melanoma tumor markers (IL-1 $\alpha$, IL-4, IL-6, IL-10, TNF- $\alpha$ and interferon- $\gamma$ ), so-called 'melanoma inhibitory activity', following phototherapy with UV light (47).

TNF- $\alpha$ is one of the most important pro-inflammatory cytokines involved in cellular proliferation, differentiation and apoptosis, and has been reported to play a critical role in carcinogenesis (48). A previous study demonstrated that protein expression and transcriptional levels of TNF- $\alpha$ were related to several promoter polymorphisms in cytokine-encoding genes, including the TNFA $-308 \mathrm{G}>\mathrm{A}$ SNP (49). In previous studies, the A allele of this SNP was associated with elevated TNF- $\alpha$ transcription in vitro (50-52), and with increased serum TNF- $\alpha$ in patients with acute myocardial infarction (53). By contrast, Sharma et al (54) reported that the A allele of the TNFA $-863 \mathrm{C}>\mathrm{A}$ SNP was associated with reduced serum TNF- $\alpha$ levels in patients with asthma (54). Similarly, the wild-type G-allele of TNFA -308G $>$ A was associated with significantly higher TNFA mRNA expression in human blood leucocytes, compared with the A allele (55).

In the current study, no differences were found in the genotype or allelic distributions between patients with CMM and the controls. This result confirms the reported lack of association between the TNFA -863C $>\mathrm{A}$ SNP and increased risk of melanoma $(13,33,56)$. By contrast, previous meta-analyses suggested that the TNFA $-308 \mathrm{G}>\mathrm{A}$ polymorphism was a risk factor for a range of other malignancies, such as gastric, breast and hepatocellular cancer (57-59), whilst other studies did not demonstrate any significant association between TNFA $-308 \mathrm{G}>\mathrm{A}$ and the risk of cancer (60).

In conclusion, the results of the present study suggested that the IL6-174G $>\mathrm{C}$ and the TNFA $-308 \mathrm{G}>\mathrm{A}$ promoter polymorphisms were not predisposing factors for CMM. However, the IL6 -174G $>$ C SNP and IL-6 serum concentrations are likely to influence the progression of CMM. The GG geno- 
type and higher serum levels may be associated with tumor progression and shorter survival. Although the GG genotype was associated with lower IL-6 levels, higher IL-6 levels may be influenced by other factors, including sun light, and not only by the genotype.

\section{Acknowledgements}

The authors would like to thank Dr Petya Peeva of the Dermatology Unit of The Oncology Center (Stara Zagora, Bulgaria) for providing patient clinical data and biological materials. The present study was previously presented at the 2nd International Multicenter European Cooperation in Science and Technology Action (no. CA15129) on Diagnosis, Monitoring and Prevention of Exposure Conference, Bentivoglio, near Bologna, Italy, 30-31 October 2017 and the Abstract was published in a supplement of the Journal of Health and Pollution.

\section{Funding}

The present study was supported by The Medical Faculty of Trakia University (grant no. 1/2018), The National Scientific Program for Support of Young Scientists and Post-doctoral Scientists administered by The Ministry of Education and Science (grant no. 577/17.08.2018), and by COST Action (grant no. CA15129; DiMoPEX).

\section{Availability of data and materials}

The datasets used and/or analyzed during the present study are available from the corresponding author on reasonable request.

\section{Authors' contributions}

TV, MK, MD and DV conceived and designed the study. TV, DD, DV and NO wrote and revised the manuscript. TV, AA and MK performed the genotyping. TV, TT, DD, DV and AM collected the biological material and clinical data, and analyzed the data. DD and AM acquired the informed consent and approval by the Ethics Committee, and were involved in drafting the manuscript. All authors contributed to the writing of the manuscript. All authors read and approved the final manuscript.

\section{Ethics approval and consent to participate}

Written informed consent was obtained from all participants included in the study. The study protocol was approved by The Ethics Committee at The Medical Faculty of Trakia University. The present study was performed in accordance with the ethical standards laid down in the 1964 Declaration of Helsinki and its later amendments, or comparable ethical standards.

\section{Patient consent for publication}

Not applicable.

\section{Competing interests}

The authors declare that they have no competing interests.

\section{References}

1. Dimitrova N, Vukov M and Valerianova Z: Cancer incidence in Bulgaria. 2013 National Oncological Hospital, Bulgarian National Cancer Registry, Publisher AVIS-24 Ltd 24: 1-171, 2015.

2. Balch CM, Soong SJ, Murad TM, Smith JW, Maddox WA and Durant JR: A multifactorial analysis of melanoma. IV. Prognostic factors in 200 melanoma patients with distant metastases (stage III). J Clin Oncol 1: 126-134, 1983.

3. Barth A, Wanek LA and Morton DL: Prognostic factors in 1,521 melanoma patients with distant metastases. J Am Coll Surg 181: 193-201, 1995. [see comments].

4. Brand CU, Ellwanger U, Stroebel W, Meier F, Schlagenhauff B, Rassner $\mathrm{G}$ and Garbe C: Prolonged survival of 2 years or longer for patients with disseminated melanoma. An analysis of related prognostic factors. Cancer 79: 2345-2353, 1997.

5. Mössner R, Anders N, König IR, Krüger U, Schmidt D, Berking C, Ziegler A, Brockmöller J, Kaiser R, Volkenandt M, et al: Variations of the melanocortin-1 receptor and the glutathione-S transferase $\mathrm{T} 1$ and $\mathrm{M} 1$ genes in cutaneous malignant melanoma. Arch Dermatol Res 298: 371-379, 2007.

6. Schoof N, von Bonin F, König IR, Mössner R, Krüger U, Reich K, Berking C, Volkenandt M, Ziegler A, Böckmann L, et al: Distal and proximal interleukin (IL)-10 promoter polymorphisms associated with risk of cutaneous melanoma development: A case--control study. Genes Immun 10: 586-590, 2009.

7. Bishop DT, Demenais F, Iles MM, Harland M, Taylor JC, Corda E, Randerson-Moor J, Aitken JF, Avril MF, Azizi E, et al: Genome-wide association study identifies three loci associated with melanoma risk. Nat Genet 41: 920-925, 2009.

8. Landi MT, Kanetsky PA, Tsang S, Gold B, Munroe D, Rebbeck T, Swoyer J, Ter-Minassian M, Hedayati M, Grossman L, et al: MC1R, ASIP, and DNA repair in sporadic and familial melanoma in a Mediterranean population. J Natl Cancer Inst 97: 998-1007, 2005.

9. Dolzan V, Rudolf Z and Breskvar K: Genetic susceptibility to environmental carcinogenesis in Slovenian melanoma patients. Acta Dermatovenerol Alp Pannonica Adriat 15: 69-78, 2006.

10. Wei Q, Lee JE, Gershenwald JE, Ross MI, Mansfield PF, Strom SS, Wang LE, Guo Z, Qiao Y, Amos CI, et al: Repair of UV light-induced DNA damage and risk of cutaneous malignant melanoma. J Natl Cancer Inst 95: 308-315, 2003.

11. Lear JT, Smith AG, Strange RC and Fryer AA: Detoxifying enzyme genotypes and susceptibility to cutaneous malignancy. Br J Dermatol 142: 8-15, 2000.

12. Fargnoli MC, Argenziano G, Zalaudek I and Peris K: Highand low-penetrance cutaneous melanoma susceptibility genes. Expert Rev Anticancer Ther 6: 657-670, 2006.

13. Howell WM, Turner SJ, Collins A, Bateman AC and Theaker JM: Influence of TNFalpha and LTalpha single nucleotide polymorphisms on susceptibility to and prognosis in cutaneous malignant melanoma in the British population. Eur $\mathrm{J}$ Immunogenet 29: 17-23, 2002.

14. Passarelli A, Mannavola F, Stucci LS, Tucci M and Silvestris F: Immune system and melanoma biology: A balance between immunosurveillance and immune escape. Oncotarget 8: 106132-106142, 2017.

15. Lázár-Molnár E, Hegyesi H, Tóth S and Falus A: Autocrine and paracrine regulation by cytokines and growth factors in melanoma. Cytokine 12: 547-554, 2000.

16. Hirano T: Interleukin 6 and its receptor: Ten years later. Int Rev Immunol 16: 249-284, 1998.

17. Ohl $\mathrm{K}$ and Tenbrock K: Inflammatory cytokines in systemic lupus erythematosus. J Biomed Biotechnol 2011: 432595, 2011.

18. Chang Q, Bournazou E, Sansone P, Berishaj M, Gao SP, Daly L, Wels J, Theilen T, Granitto S, Zhang X, et al: The IL-6/JAK/Stat3 feed-forward loop drives tumorigenesis and metastasis. Neoplasia 15: 848-862, 2013.

19. Tobin RP, Jordan KR, Kapoor P, Spongberg E, Davis D, Vorwald VM, Couts KL, Gao D, Smith DE, Borgers JSW, et al: IL-6 and IL-8 are linked with myeloid-derived suppressor cell accumulation and correlate with poor clinical outcomes in melanoma patients. Front Oncol 9: 1223, 2019.

20. Hoejberg L, Bastholt L, Johansen JS, Christensen IJ, Gehl J and Schmidt H: Serum interleukin-6 as a prognostic biomarker in patients with metastatic melanoma. Melanoma Res 22: 287-293, 2012.

21. Vlaykova T: Prognostic factors in metastatic melanoma: special reference to tumor vascularity, proliferation and $\mathrm{Bcl}-2$ expression. Turku University, Turku, Finland, 2002. 
22. Linnskog R, Jönsson G, Axelsson L, Prasad CP and Andersson T: Interleukin-6 drives melanoma cell motility through p38 $\alpha$-MAPK-dependent up-regulation of WNT5A expression. Mol Oncol 8: 1365-1378, 2014.

23. Na YR, Lee JS, Lee SJ and Seok SH: Interleukin-6-induced Twist and N-cadherin enhance melanoma cell metastasis. Melanoma Res 23: 434-443, 2013.

24. Rossi S, Cordella M, Tabolacci C, Nassa G, D'Arcangelo D, Senatore C, Pagnotto P, Magliozzi R, Salvati A, Weisz A, et al: TNF-alpha and metalloproteases as key players in melanoma cells aggressiveness. J Exp Clin Cancer Res 37: 326, 2018.

25. Donia M, Kjeldsen JW and Svane IM: The controversial role of TNF in melanoma. OncoImmunology 5: e1107699, 2018.

26. Bertrand F, Rochotte J, Colacios C, Montfort A, Andrieu-Abadie N, Levade T, Benoist H and Ségui B: Targeting TNF alpha as a novel strategy to enhance CD8+ T cell-dependent immune response in melanoma? OncoImmunology 5: e1068495, 2015.

27. Zhai K, Yang Y, Gao ZG and Ding J: Interleukin-6-174G $>C$ gene promoter polymorphism and prognosis in patients with cancer. Oncotarget 8: 44490-44497, 2017.

28. Banday MZ, Balkhi HM, Hamid Z, Sameer AS, Chowdri NA and Haq E: Tumor necrosis factor- $\alpha$ (TNF- $\alpha)-308 \mathrm{G} / \mathrm{A}$ promoter polymorphism in colorectal cancer in ethnic Kashmiri population - A case control study in a detailed perspective. Meta Gene 9: 128-136, 2016.

29. Kroeger KM, Steer JH, Joyce DA and Abraham LJ: Effects of stimulus and cell type on the expression of the -308 tumour necrosis factor promoter polymorphism. Cytokine 12: 110-119, 2000.

30. Zhuang L, Ma W, Cai D, Zhong H and Sun Q: Associations between tumor necrosis factor- $\alpha$ polymorphisms and risk of psoriasis: A meta-analysis. PLoS One 8: e68827, 2013.

31. Howell WM, Turner SJ, Theaker JM and Bateman AC: Cytokine gene single nucleotide polymorphisms and susceptibility to and prognosis in cutaneous malignant melanoma. Int $\mathrm{J}$ Immunogenet 30: 409-414, 2003.

32. Nikolova PN, Pawelec GP, Mihailova SM, Ivanova MI, Myhailova AP, Baltadjieva DN, Marinova DI, Ivanova SS and Naumova EJ: Association of cytokine gene polymorphisms with malignant melanoma in Caucasian population. Cancer Immunol Immunother 56: 371-379, 2007.

33. Gu F, Qureshi AA, Niu T, Kraft P, Guo Q, Hunter DJ and Han J: Interleukin and interleukin receptor gene polymorphisms and susceptibility to melanoma. Melanoma Res 18: 330-335, 2008.

34. Gu F, Qureshi AA, Kraft P, Guo Q, Hunter DJ and Han J: Polymorphisms in genes involved in DNA repair, cell growth, oxidative stress and inflammatory response, and melanoma risk. Br J Dermatol 161: 209-212, 2009.

35. Kurzawski M, Pawlik A, Czerny B, Domański L, Rózański J and Droździk M: Frequencies of the common promoter polymorphisms in cytokine genes in a Polish population. Int J Immunogenet 32: 285-291, 2005.

36. Garbe C, Ellwanger U, Tronnier M, Brocker EB and Orfanos CE: The New American Joint Committee on Cancer staging system for cutaneous melanoma: A critical analysis based on data of the German Central Malignant Melanoma Registry. Cancer 94: 2305-2307, 2002.

37. Dickson PV and Gershenwald JE: Staging and prognosis of cutaneous melanoma. Surg Oncol Clin N Am 20: 1-17, 2011.

38. Zarogoulidis P, Yarmus L, Darwiche K, Walter R, Huang H, Li Z, Zaric B, Tsakiridis K and Zarogoulidis K: Interleukin-6 cytokine: A multifunctional glycoprotein for cancer. Immunome Res 9: 16535, 2013.

39. Gomes M, Coelho A, Araújo A, Azevedo A, Teixeira AL, Catarino R and Medeiros R: IL-6 polymorphism in non-small cell lung cancer: A prognostic value? Tumour Biol 36: 3679-3684, 2015.

40. Lu C, Vickers MF and Kerbel RS: Interleukin 6: A fibroblast-derived growth inhibitor of human melanoma cells from early but not advanced stages of tumor progression. Proc Natl Acad Sci USA 89: 9215-9219, 1992.

41. Fishman D, Faulds G, Jeffery R, Mohamed-Ali V, Yudkin JS, Humphries S and Woo P: The effect of novel polymorphisms in the interleukin-6 (IL-6) gene on IL-6 transcription and plasma IL-6 levels, and an association with systemic-onset juvenile chronic arthritis. J Clin Invest 102: 1369-1376, 1998.

42. Terry CF, Loukaci V and Green FR: Cooperative influence of genetic polymorphisms on interleukin 6 transcriptional regulation. J Biol Chem 275: 18138-18144, 2000.

43. Jones KG, Brull DJ, Brown LC, Sian M, Greenhalgh RM, Humphries SE and Powell JT: Interleukin-6 (IL-6) and the prognosis of abdominal aortic aneurysms. Circulation 103: 2260-2265, 2001.
44. Martínez-Escribano JA,Moya-Quiles MR,Muro M,Montes-Ares O, Hernández-Caselles T, Frías JF and Alvarez-López MR: Interleukin-10, interleukin-6 and interferon-gamma gene polymorphisms in melanoma patients. Melanoma Res 12: 465-469, 2002

45. Gautam KA, Muktanand T, Sankhwar SN, Goel A, Sankhwar PL and Rajender S: Functional polymorphisms in the IL6 gene promoter and the risk of urinary bladder cancer in India. Cytokine 77: 52-156, 2016.

46. Leibovici D, Grossman HB, Dinney CP, Millikan RE, Lerner S, Wang Y, Gu J, Dong Q and Wu X: Polymorphisms in inflammation genes and bladder cancer: From initiation to recurrence, progression, and survival. J Clin Oncol 23: 5746-5756, 2005.

47. Datz E, Zeman F, Koller M, Szeimies RM, Berneburg M, Landthaler M, Bosserhoff AK and Karrer S: Phototherapy-induced elevation of serum level of melanoma inhibitory activity. Photodermatol Photoimmunol Photomed 35: 255-260, 2019.

48. Aggarwal BB, Gupta SC and Kim JH: Historical perspectives on tumor necrosis factor and its superfamily: 25 years later, a golden journey. Blood 119: 651-665, 2012.

49. Messer G, Spengler U, Jung MC, Honold G, Blömer K, Pape GR, Riethmüller $\mathrm{G}$ and Weiss EH: Polymorphic structure of the tumor necrosis factor (TNF) locus: An NcoI polymorphism in the first intron of the human TNF-beta gene correlates with a variant amino acid in position 26 and a reduced level of TNF-beta production. J Exp Med 173: 209-219, 1991.

50. Wilson AG, di Giovine FS, Blakemore AI and Duff GW: Single base polymorphism in the human tumour necrosis factor alpha (TNF alpha) gene detectable by NcoI restriction of PCR product. Hum Mol Genet 1: 353, 1992.

51. Kroeger KM, Carville KS and Abraham LJ: The -308 tumor necrosis factor-alpha promoter polymorphism effects transcription. Mol Immunol 34: 391-399, 1997.

52. Zhang S, Wang C, Xi B and Li X: Association between the tumour necrosis factor- $\alpha-308 \mathrm{G} / \mathrm{A}$ polymorphism and chronic obstructive pulmonary disease: An update. Respirology 16, 107-115: 2011.

53. Ghaderian SM, Akbarzadeh Najar R and Tabatabaei Panah AS: Tumor necrosis factor- $\alpha$ : Investigation of gene polymorphism and regulation of TACE-TNF- $\alpha$ system in patients with acute myocardial infarction. Mol Biol Rep 38: 4971-4977, 2011.

54. Sharma S, Sharma A, Kumar S, Sharma SK and Ghosh B Association of TNF haplotypes with asthma, serum IgE levels, and correlation with serum TNF-alpha levels. Am J Respir Cell Mol Biol 35: 488-495, 2006.

55. Helmig S, Aliahmadi N, Stephan P, Döhrel J and Schneider J: TNF- $\alpha-308$ genotypes are associated with TNF- $\alpha$ and TGF- $\beta$ mRNA expression in blood leucocytes of humans. Cytokine 53: 306-310, 2011.

56. Liu N, Liu Gj and Liu J: Genetic association between TNF- $\alpha$ promoter polymorphism and susceptibility to squamous cell carcinoma, basal cell carcinoma, and melanoma: A meta-analysis. Oncotarget 8 (32): 53873-53885, 2017.

57. Wang J, Cao C, Luo H, Xiong S, Xu Y and Xiong W: Tumour necrosis factor- $\alpha-308 \mathrm{G} / \mathrm{A}$ polymorphism and risk of the four most frequent cancers: a meta-analysis. Int J Immunogenetics 38: 311-320, 2011.

58. Gorouhi F, Islami F, Bahrami $\mathrm{H}$ and Kamangar F: Tumour-necrosis factor-A polymorphisms and gastric cancer risk: A meta-analysis. Br J Cancer 98: 1443-1451, 2008.

59. Yang Y, Feng R, Bi S and Xu Y: TNF-alpha polymorphisms and breast cancer. Breast Cancer Res Treat 129: 513-519, 2011.

60. Min L, Chen D, Qu L and Shou C: Tumor necrosis factor-a polymorphisms and colorectal cancer risk: A meta-analysis. PLoS One 9: e85187, 2014.

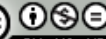

This work is licensed under a Creative Commons Attribution-NonCommercial-NoDerivatives International (CC BY-NC-ND 4.0) License. 